\title{
PROFESSIONAL IDENTITY FORMATION PROCESS OF A DANCE TEACHER
}

\begin{abstract}
In the modern society the concept of professional identity is topical in many different occupations. The professional identity of the dance teacher has not been researched scientifically and there are no studies about this concept. The article focuses on the formation process of the dance teacher's professional identity as well as the professional identity model. The aim of this article is to view the professional identity formation process in a profession of a dance teacher and to create a professional identity model of the dance teacher by analysing scientific literature and using professional experience. The professional activity of the dance teacher directly affects the students in any age group from toddlers to seniors, both physically and psychologically; therefore, it is especially important to pay attention to the issues of dance teacher's professional identity, or even the lack of information about the professional identity itself. If the questions of professional identity are not discussed in the study process and there are no related instructions or materials that reveal the essence of the professional identity concept in the world of dance, then the knowledge gained in higher education and practice can be interpreted as unnecessary for the profession. As a result of this study there is formed a professional identity model of a dance teacher. Explaining professional identity leads to greater insight into one's profession, as well as quality assessment of one's professional work and achievements.
\end{abstract}

Keywords: dance pedagogy, dance teacher, professional identity, professional identity model.

\section{Introduction}

In the fast rhythm of the today's society and in the wide range of opportunities there are more people that spend great deal of their spare time in their workplace, or even, as they say, "bring work home". It is necessary for people to know and understand their identity, to follow the goals, and not less to have a greater insight in professional identity. 
Palmer (2016) states that studies on professional identity consider not only what teachers know and/or believe but also who they are, how they view themselves as teachers, how they relate to students, how they deal with problems, how they reflect on issues, and how they identify themselves within the profession.

In the creative industries there is a thin line between the work hours and spare time. These professions are more like a way of life than just a job. Before a class, dance teacher forms new exercises, searches for a new musical material, review the structure of the future lesson, creates new choreography and other necessary things for a successful dance class. After work a dance teacher designs dance costumes, promotional materials and gets in contact with the specialists from other professions to organize the concert activities. Styrke (2015) affirm that in a time of constant change, dance teaching certainly deals with changing didactic conditions, curricular as well as contextual and social.

In the profession of a dance teacher the higher education gives a specific additional knowledge, but not a basic one. Similarly music students practice even before entering elementary school, to be ready for their profession. Upcoming professionals in the art of dance also must be educated in dance from childhood before entering higher education. In Latvia there is a lack of professional art schools where youth can learn different dance skills as a future professionals. There are only some private dance studios that are accredited as schools, but mainly a profession of a dancer is either obtainable in the Riga Choreography High School, or is in a level of additional after class studies.

With a problem like this, there are even more reason to look in the direction of professional identity formation and its content, to understand a way the teachers feel and how they perceives their profession in a society where dance is only a way to spend ones free time and get fit, but not as a serious profession which requires education and non-stop development.

\section{Methods and Materials}

In this article the main emphasis concerning the research methods is the analysis of scientific literature. The topic of professional identity is still opened for new research and there are variety of discussions about methods of research and especially the content of professional identity.

In the framework of this study the concept of identity was reviewed from philosophical point of view. The course of the study of Identity and Professional Identity gained a phenomenological set. Researching the concept of professional identity the author encountered researches of the following authors: A. Spona, M. Vidnere, J. Jermolajeva, J. Jakovleva, 
M. J. Fernandez Gonzales, A. Griffin, D. Beijaard, G. J. Knowles, J. Nias, N. Verloop and others. Selecting the required scientific literature, the author of this study used such databases as: WEB of science, EBSCO, APPA gold, SCOPUS, Science Direct. There were revised a list of dissertations from 2010 till 2017, but as the necessary information was insufficient the limitations in time were cancelled. The keywords were "identity", "professional identity", "teachers professional identity", "dance teachers professional identity", "dance teacher", "dance pedagogy". From the gained results the researcher selected 25 articles, 9 doctoral dissertations about remotely close topics in dance, sports, music, pedagogy and 2 dissertations about professional identity. None of the selected sources (using the mentioned key words) did not offer any researches about professional identity of a dance teacher. The closest topics to the selected concept were "teachers professional identity", "professional identity integration of a music teacher and performer".

As there is no scientifically based information about dance teachers professional identity author of this article researched literature on the topic "teachers professional identity".

Beijaard, Meijer, Verloop (2000) investigated experienced secondary school teachers' current and prior perceptions of their professional identity. In their research of teachers' perceptions of professional identity, authors explored the way teachers derived their professional identity from (mostly combinations of) the ways they saw themselves as subject matter experts (Hoyle, John, 1995; Bennett, Carre, 1993; Calderhead, 1996), pedagogical experts (Beijaard, 1995; Damon, 1992; Oser, 1992), and didactical experts (Beijaard, 1990; Doyle, 1990; Vermunt, 1995). In European studies and teaching practices, these are common concepts to indicate what a teacher should know and be able to do (Beijaard, Meijer, Verloop, 2000).

The concept of identity is defined in various ways in the more general literature. It seems that the concept of professional identity is also used in different ways in the domain of teaching and teacher education (Beijaard, Meijer, Verloop, 2004). In some studies, the emphasis was placed on the roles that teachers take over in their professional work (Goodson, Cole, 1994; Volkmann, Anderson, 1998), whether or not in relationship with other concepts, or on concepts like reflection or self-evaluation that are important for the development of professional identity (Cooper, Olson, 1996; Kerby, 1991). In other studies, the concept of professional identity was related to the images of self (Knowles, 1992; Nias, 1989). It was discussed that these concepts or images of self strongly determine the way teachers teach, the way they develop as teachers, and their attitudes toward educational changes. Furthermore, professional identity refers not only to the influence of the conceptions and expectation of other people, including broadly accepted images in society about what a teacher should 
know and do, but also what teachers themselves find important in their professional work and lives based on both their experiences in practice and their personal backgrounds (Tickle, 1999).

In 2004 Beijaard, Meijer and Verloop conducted another research of the literature on teacher's professional identity to the period 1988-2000, because it was in this period that teachers' professional identity emerged as a research area. All together there were analysed 22 studies relevant to the topic. Concerning teachers' professional identity formation, the authors conclude that teacher's biographies and beliefs that are determined by these biographies are conceived of as important constituents of teachers' professional identity formation (Beijaard, Meijer, Verloop, 2004). The research on teachers' professional identity formation also contributes to understanding and acknowledgment of what it feels like to be a teacher in today's schools, where many things are changing rapidly, such as - teaching methods, movement techniques, emerging and combining dance styles, contemporary view on choreography, new technology, and how teachers cope with these changes. In addition to this fact Beijaard, Meijer and Verloop (2004) pay attention to the teacher's personal part of professional identity and that inner conflict can lead to friction in teachers' professional identity in cases in which the 'personal' and the 'professional' are too far removed from each other.

There are three main factors that influence the definition of teacher's professional identity:

- Professional identity is not a stable entity; it cannot be interpreted as fixed or unitary (Coldron, Smith, 1999). It is a complex and dynamic equilibrium where professional self-image is balanced with a variety of roles teachers feel that they have to play (Volkmann, Anderson, 1998);

- Cooper and Olson (1996) pointed to the fact that professional identity is multifaceted. Historical, sociological, psychological, and cultural factors may all influence the teacher's sense of self as a teacher. Furthermore, professional identity may consist of many subidentities that may conflict or align with each other (Mishler, 1999);

- A final remark pertaining to the definition of professional identity concerns the emphasis on the 'personal' and an underestimation of the contextual side that plays a part in professional identity formation. Reynolds (1996) emphasized that what surrounds a person, what others expect from the person, and what the person allows to impact on him or her greatly affect his or her identity as a teacher.

Most recent researches (Olsen, Buchanan, 2017) state that professional identity is not only the ongoing process of a teacher continually relying on his or her self-understandings to make meaning out of present experience 
but is also the resulting, dynamic product of knowledge, goals, and selfunderstandings that is enacted in everyday practice.

Thomas and Mockler (2018) argues that in the same way as it appears that professional identity cannot be framed in terms of professional knowledge, neither can it be framed in terms of experience in the way Beijaard, Meijer and Verloop contend. Thrue the wide discussions within the research Thomas and Mockler (2018) suggest that teachers' subidentities interplay in a complex way in the formation of their professional identities.

Looking up the experience in Latvian scientific researches there are several doctoral dissertations on the concept of professional identity. Jakovleva (Jakovleva, 2009) analyzed identity theories concerning professional identity. Fernández González (2012) analysed performer and teacher identity integration in the pedagogical work of musical instrument performer students.

Estimating the person's identity and professional identity formation process, Fernández González (2012) developed professional identity formation process model, which includes person's psychological, actual and social aspects of profession: formation of the ideal image of professional; choosing a profession; involvement in professional activity and personal and social recognition.

Spona, Vidnere and Jermolajeva (Професиональная идентичность neдагога, 2016), in the collective monography on teacher's professional identity in higher education institutions (Riga - Latvia, Smolensk - Russia), promote the following professional identity components: professional philosophy; professional knowledge and skills; professional roles; interaction with colleagues; professional representation. A part of the authors of this monography proposed to include in the model such components as: endurance and tolerance. Besides, they suggested to create an outer circle of secondary components which affect professional identity.

\section{Results and Discussions}

As a result of scientific literature analysis and using professional practice and experience in the field of dance pedagogy there is developed a professional identity model of a dance teacher (see Figure 1).

This model consists of professional identity components and they form a core circle. The components are professional philosophy and values. The values are a basis of professional activities and life in general. Professional philosophy consists of beliefs, goals of professional work, professional ethics, the most important notions about the profession; professional knowledge and skills that are obtained not only in the higher education 
but also in the early dance education; professional roles can vary, including an educator, teacher, choreographer, dancer, organizer of events and manager. There can be primary roles in a daily work and secondary roles that are useful to engage properly in the profession; artistically creative work is an innovative component. The work of an art teacher including a dance teacher cannot be cut off from creativity and artistically creative work which results in a work of art - a dance; professional attitude towards work presents an attitude towards the profession itself and promotes such terms as suitability for the profession, values and cultural behaviour; image of the professional. In the world of dance there is a certain image that society awaits from a dancer and a dance teacher. The image promotes not only a certain behaviour but also appearance. Considering the teacher himself - the image can vary from a friend to a highly trained professional.

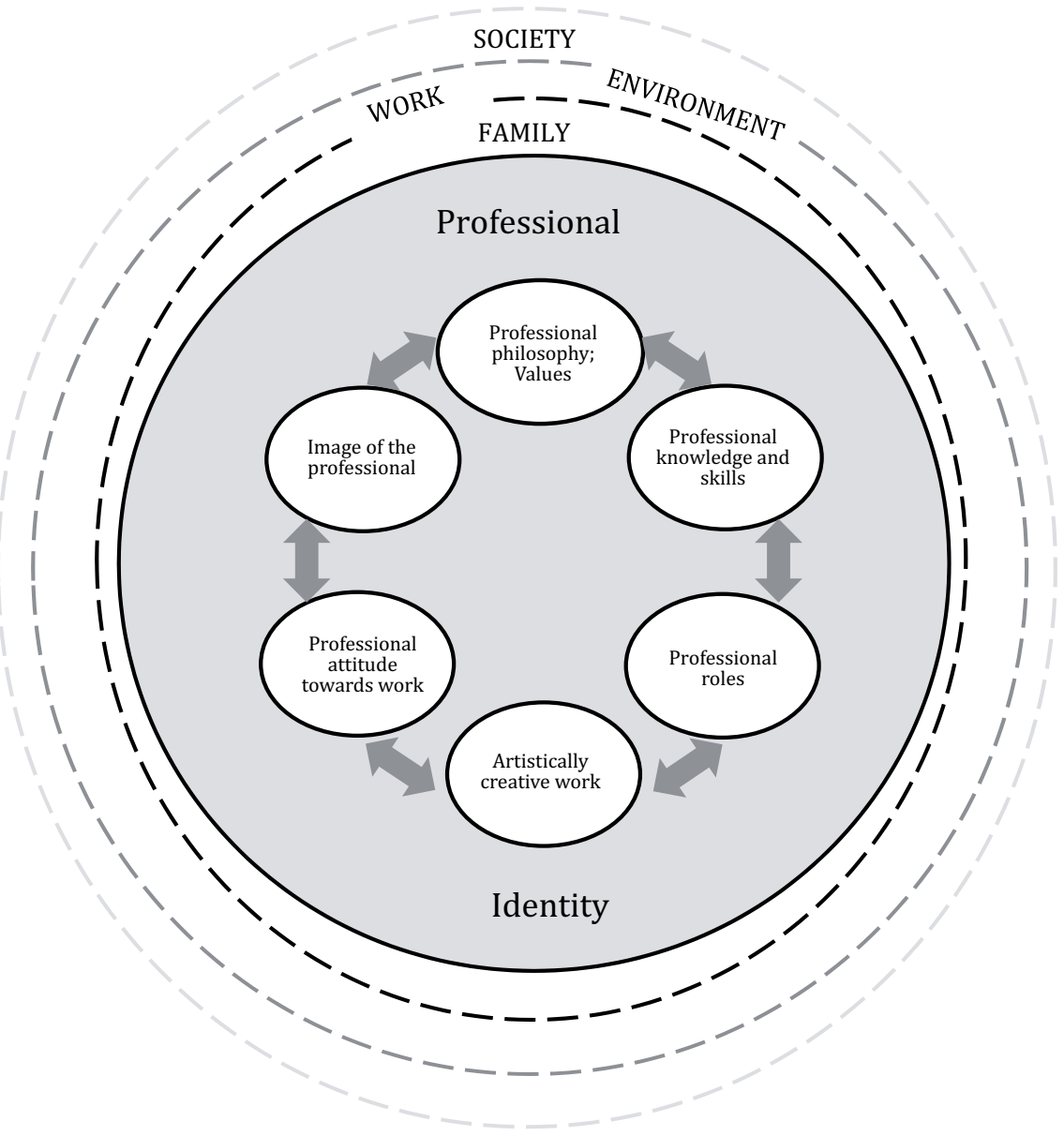

Figure 1. Professional identity model of a dance teacher 
Outer circles represent outer influence factors that affect dance teacher's professional identity. First of all, a family can greatly influence professional identity of an artistic profession. Professions which represent different forms of art are a way of life and thinking. Spare time overlaps with work frequently, the artistic and concert activities take place on weekends or even on holidays and celebration, therefore a supportive family attitude can promote professional identity and vice versa. Work environment is another important factor of influence in every profession - supportive work colleagues/boss, pleasant dance hall, appropriate salary/pay, appreciation and helpfulness if necessary. Society can influence professional identity in terms of prejudice, incorrect notion about the profession, incomprehension, but also recognition, appreciation.

\section{Conclusions}

- Professional identity is an ongoing process that changes over the time and under different circumstances.

- Professional identity is an open and topical subject to be discussed, especially in the field of dance pedagogy, because there are no related researches publicized and available on this topic.

- Dance teachers professional identity formation process should be traced back to early childhood experience.

- There are variety of methods to apply on measuring the professional identity of a dance teacher sarting from a survey to bibliographical stories.

- The content of professional identity may change according to the selected profession.

- Professional identity of a dance teacher consists of professional philosophy and values, professional knowledge and skills, professional roles, artistically creative work, professional attitude towards work and image of the professional.

- Artistically creative work is an important component of professional identity of a dance teacher and is essential to their professional activity.

- Society, family, work environment are the main outer factors that influence dance teachers professional identity.

- It is necessary to include the topic of "Professional Identity" into the curriculum of higher education of dance teachers/choreographers to create greater insight into one's profession, as well as quality assessment of one's professional work and achievements. 


\section{References}

Beijaard, D. (1990). Teaching as acting: A reconstructive study of an action theoretical approach to research and development in the domain of teaching. Wageningen Agricultural University: Department of Education.

Beijaard, D. (1995). Teachers' prior experiences and actual perceptions of professional identity. Teachers and Teaching: Theory and Practice, 1, 281-294.

Beijaard, D., Meijer, P. C., Verloop, N. (2000). Teachers' perceptions of professional identity: an exploratory study from a personal knowledge perspective. Teaching and Teacher Education, 16, 749-764.

Beijaard, D., Meijer, P. C., Verloop, N. (2004) Reconsidering research on teachers' professional identity. Teaching and Teacher Education, 20, 107-128.

Bennett, N., Carre, H, J. C. (1993). Learning to teach. London: Routledge.

Calderhead, J. (1996). Teachers: Beliefs and knowledge. In: D. C. Berliner, \& R. C. Calfee, Handbook of educational psychology (pp. 709-725). New York: Macmillan.

Coldron, J., Smith, R. (1999). Active location in teachers' construction of their professional identities. Journal of Curriculum Studies, (31)6, 711-726.

Cooper, K., Olson, M. R. (1996). The multiple \&I's' of teacher identity. In: M. Kompf, W. R. Bond, D. Dworet, \& R. T. Boak, Changing research and practice: Teachers + professionalism, identities and knowledge (pp. 78-89). London: Falmer Press.

Damon, W. (1992). Teaching as a moral craft and developmental expedition. In: F. K. Oser, A. Dick, \& J. L. Patry, Effective and responsible teaching (pp. 139-153). San Francisco: Jossey-Bass.

Doyle, W. (1990). Themes in teacher education research. In: W. R. Houston, Handbook of research on teacher education (pp. 3-23). New York: Macmillan.

Fernández González, M. J. (2012). Atskañotājmākslinieka un pedagoga identitāšu integrācija mūzikas instrumentu spēles studentu pedagoǵiskajā darbībā. Promocijas darbs pedagoóijā (Doctoral disertation). Rīga: Latvijas Universitāte.

Goodson, I. F., Cole, A. L. (1994). Exploring the teacher's professional knowledge: constructing identity and community. Teacher Education Quarterly, 21(1), 85-105.

Hoyle, E., John, P. D. (1995). Professional knowledge and professional practice. London: Cassell.

Jakovḷeva, J. (2009). Profesionālā identitāte profesijas apguves sākumposmā. Promocijas darbs sociālajā psiholog̣ijā (Doctoral disertation). Daugavpils: Daugavpils Universitāte.

Kerby, A. (1991). Narrative and the self. Bloomington: Indiana University Press.

Knowles, J. G. (1992). Models for understanding pre-service and beginning teachers' biographies: Illustrations from case studies. In: I. F. Goodson, Studying teachers + lives (pp. 99-152). London: Routledge.

Mishler, E. G. (1999). Storylines: Craft artists' narratives of identity. Cambridge, MA: Harvard University Press.

Nias, J. (1989). Teaching and the self. In: M. L. Holly, \& C. S. McLoughlin, Perspectives on teachers + professional development (pp. 155-171). London: Falmer Press.

Olsen, B., Buchanan, R. (2017). Everyone wants you to do everything: Investigating the professional identity development of teacher educators. Teacher education quarterly, Winter 2017, 9-34. 
Oser, F. K. (1992). Morality in professional action: A discourse approach for teaching. In: F. K. Oser, A., Dick, and J. L., Patry, Effective and responsible teaching (pp. 109-125). San Francisco: Jossey-Bass.

Palmer, H. (2016). Professional primary school teacher identity development: a pursuit in line with an unexpected image. Teacher development, 20(5), 682-700.

Profesional'naja identichnost' pedagoga:sravnitel'noe mezhdunarodnoe issledovanie (2016). N. P. Senchenkova, A. P. Shpona (Eds.). Smolensk: SmolGU, 2016.

Reynolds, C. (1996). Cultural scripts for teachers: Identities and their relation to workplace landscapes. In: M. Kompf, W. R. Bond, D. Dworet, \& R. T. Boak (Eds.), Changing research and practice: Teachers' professionalism, identities and knowledge (pp. 69-77). London, Washington, DC: The Falmer Press.

Styrke, B. M. (2015). Didactics, dance and teacher knowing in an upper secondary school context. Research in dance education, 16(3), 201-212.

Thomas, M. A. M., Mockler, N. (2018). Alternative routes to teacher professional identity: Exploring the conflated sub-identities of teach for America Corps Members. Education policy analysis archives, 26(6).

Tickle, L. (1999). Teacher self-appraisal and appraisal of self. In: R. P. Lipka, \& T. M. Brinthaupt, The role of self in teacher development (pp. 121-141). New York: State University of New York Press.

Vermunt, J. D. (1995). Process-oriented instruction in learning and thinking strategies. European Journal of Psychology of Education, 10, 325-349.

Volkmann, M. J., Anderson, M. A. (1998). Creating professional identity: Dilemmas and metaphors of a first-year chemistry teacher. Science Education, 82(3), 293-310. 